\title{
Lessons from the Press Box: What Sportswriters Can Teach Academics
}

David S Glenwick*

Department of Psychology, Fordham University, USA

*Corresponding author: David S Glenwick, Department of Psychology, Fordham University, USA, Tel: 718-817-3790; Fax: 718-817-3785, E-mail: glenwick@fordham.edu

Rec date: Mar 04, 2014; Acc date: May 08, 2014; Pub date: May 15, 2014

Copyright: (c) 2014 Glenwick DS. This is an open-access article distributed under the terms of the Creative Commons Attribution License, which permits unrestricted use, distribution, and reproduction in any medium, provided the original author and source are credited.

Sportswriting and academic writing might initially seem to be strange bedfellows. They have different structures--the inverted pyramid with emphasis on the lead versus, for example, the four-part format (introduction/literature review, method, results, and discussion) of the typical research paper. Their audiences also differthe broad Mr./Ms. Everyperson of sportswriting as opposed to the specialized highly educated audience of academia. However, upon closer examination, they have more in common than might first appear, with sportswriting providing lessons that academic writers could profitably draw upon.

One might argue that general lessons for, and analogies to, academic writing could be drawn from almost any profession or even hobby. However, sportswriting is, I believe, a particularly apt source for specific lessons for academic writing, given that both involve purposeful, length-delimited nonfiction writing carried out with an imagined and intended reader in mind. The following are ten of these lessons, based on approximately 40 years of publishing in academia. Looking back on these years, I can see how my 4 years of being a sportswriter for my undergraduate campus newspaper helped, unbeknownst at the time, to prepare me for my later academic career.

- Be succinct. Sportswriters are usually given a certain number of "inches" (which can be translated into lines) by their editor. Similarly, academic research papers or book chapters typically have a page limit, which must be adhered to. You learn to say what you need to say within these limits.

- Be able to write under pressure. Sportswriters have deadlines. If your piece on this evening's hockey game is needed by $11 \mathrm{pm}$, you can't wait for inspiration. As the veteran sportswriter Vic Ziegel wrote, "The deadline is the enemy. You relax your finger and it comes closer. It grows closer and towers over you" [1]. This is good training for the self-discipline required of academics when submitting convention/conference papers or grant proposals, which have hard deadlines, as well as for being a productive publisher in general.

- Write clearly. Newspaper readers give you one shot--they're not going to reread a sentence. Similarly, in academic writing, say it so that your reader gets it the first time.

- Minimize jargon. Trying to reach a mass audience, sportswriters avoid obfuscatory words (like "obfuscatory") and use arcane language only when necessary (and then break it down so that the reader understands it). Although academic writing often requires the use of technical and scientific terminology, jargon should be kept to a necessary minimum and specialized terms always defined. And almost always, don't use an esoteric word when a more down-to-earth one will do.

- Write interestingly. A sportswriter wants to hook the casual reader, not just the avid fan of that school's or city's basketball team. Why should the reader care? Thus, in sportswriting the lead becomes crucial in engaging the reader, a cardinal sin being burying the lead. Likewise, in academic writing, the abstract and the introductory material are critical if anyone other than the two dozen fellow researchers in your field are going to take the time to read your article.

- Write in an organized way. In a sports article, the structure is the inverted pyramid. In empirical academic writing, it's the four-part format noted above. Organizing your writing helps you organize your thinking, thereby making you a more effective communicator.

- Write with your audience in mind. In sportswriting, your audiences are fans--both fanatic and casual. In academic writing, your audience typically consists of fellow scholars and journal editors/reviewers. Put yourself in their place as you write, asking yourself such questions as "What will they want to know?" "What do I want to emphasize?" "What details are important?" In other words, what is the forest and what are the trees, and what trees need to be in the forest?

- Write with a purpose in mind. A sports article can be a news article (for example, about the appointment of a new coach), a report on the results of a game, a profile, or an opinion piece. Each has a different purpose, and each is written in a somewhat different style. So, too, with academic writing, where research papers, review articles, and book chapters have different aims requiring different structures and styles. Illustratively, just as a sports column typically allows (indeed calls for) more opinionproviding on the part of the writer than does an article reporting on a game, so too does a book chapter usually permit more latitude of personal expression and viewpoint than does a research article.

- Write with perspective and context in mind. In a sports article, you want the reader to gain an appreciation of why this game, this team, or this player matters. What is its relationship to the team's season or to that sport in general? So too, in the case of a report of a research study, for instance, you want to be able to place your findings within the context of its discipline or subdiscipline. How does it advance the field? Where do we go from here?

- Be accurate. A sportswriter must get the facts right. If even one fact is wrong, then the writer becomes fair game for being questioned on everything and losing the reader's trust. So, too, with academic writing. Data, quotes, and reports of past research are basic and need to be correct.

So, in addition to such traditional writing aids as Strunk and White's The Elements of Style and the publication guide in one's field (such as the American Psychological Association's Publication Manual), those of us who have been sportswriters in our past lives can reflect on and benefit from that experience in developing our skills as academic writers. Prospectively, instructors in undergraduate sportswriting and related journalism courses can explicitly note the 
Citation: Glenwick DS (2014) Lessons from the Press Box: What Sportswriters Can Teach Academics. J Mass Communict Journalism 4: 192. doi:10.4172/2165-7912.1000192

Page 2 of 2

relevance of sportswriting to students' writing in other courses and to possible nonsportswriting careers that they may enter. And, finally, since the sports section tends to be one of the most heavily read sections of the newspaper (for example, finishing third, behind only the front page and local news in a 2008 survey by the Newspaper Association of America [2]), many who aren't sportswriters are readers of sports articles and can learn from good sportswriting. Thus, from the seemingly less-serious world of sports, we can become more effective written communicators in our own professional activities.

Sports journalism at its best is engaging, informative, and fresh-as is academic writing. The award-winning sportswriter Frank Deford has observed, "When people hear you're a sportswriter, they assume you're more interested in the first half of that word than the second" [3]. Such is not the case with good sportswriting, nor should it be with good academic writing.

\section{References}

1. Ziegel V (2009) The joys of being a sportswriter. Silurian News 61: 4-6.

2. Newspaper Association of America (2008) Daily newspaper section readership report. Retrieved from http://www.naa.org/media/ Readership/ Daily-Readership-Active.ashx

3. Deford F (2013) Personal communication October 27. 